\title{
THE CURRENT STATE OF E-BOOKS AND DIGITAL LIBRARIES OF JAPAN
}

\author{
Hisaki Goto, Kaichi International University, hisaki@goto.or.jp \\ Ben Kim, Seattle University, bkim@seattleu.edu \\ Kohji Inagaki, Seattle University, kohji.inagaki@gmail.com
}

\begin{abstract}
Japan is one of the major countries in terms of the number of books and e-books published in the world. In this paper we will discuss the history of e-books and digital libraries, the advantages/disadvantages of e-books, and the current state of the publishing industry and digital libraries of Japan. Finally, we will discuss how to make e-books and digital libraries more accessible and available in Japan.
\end{abstract}

Keywords: E-Books, E-Libraries, Publishers, Japan

\section{INTRODUCTION}

In the United States, e-books are rapidly replacing paper books and fundamentally changing the culture of reading and accessing information. Japan is one of the top countries in terms of the number of books and e-books published in the world. In Japan, even though electronic journals have been available for scholars and researchers for more than a decade, e-books only recently became widely available to the general public starting in 2012

An electronic book (aka e-book, eBook, e-Book, ebook, digital book, or even e-edition) is a book-length publication in a digital form, consisting of text and images, readable on computers or other electronic devices [6]. This definition also includes a scanned form of a physical book. A delivery of a scanned version without proper copyrights violates copyright laws. Thus, our definition of e-books only includes the ones with proper copyrights [8]. In this paper, we will discuss the history of e-books and digital libraries, the advantages/disadvantages of ebooks, and the current state of the publishing industry and digital libraries of Japan. Finally, we will discuss how to make e-books and digital libraries more accessible and available in Japan.

\section{HISTORY OF E-BOOKS IN JAPAN}

The first e-books or digital libraries in the world are known to have been created by Project Gutenberg led by Michael S. Hart in 1971. Project Gutenberg is a volunteer effort to digitize and archive cultural works, to "encourage the creation and distribution of eBooks" [7]. In Project Gutenberg, they digitized the books whose copyrights were expired and distributed them at no charge on the Internet. These digitized books made available on the Internet are known to have created the first digital library in the world. The Japanese version of Project Gutenberg would be Aozora Bunko that started their service in 1997 [1]. Aozora Bunko has been distributing free ebooks and has since become one of the inaugurating pioneers of Japanese digital libraries.

Even before Aozora Bunko's efforts, CD-ROM versions of e-books were available in Japan in 1985. SONY's ebook readers appeared in 1990, and NEC's digital book players in 1993. The term e-book was first used by SONY but the Japanese court did not recognize it as a trade mark, because the term was too general to be used as a particular company's product name [2]. Later on the E-Books Consortium was organized in 1999, and since 2003 novels and cartoons have become available on mobile phones. In 2004, SONY and Panasonic began to sell LIBLIe and $\Sigma$ Book, respectively. SONY's LIBLIe was adopted as an e-book reading device at the Ikoma City library, yet its popularity receded within a year. In 2010, three ministries of the central government - the Ministry of Internal Affairs and Communications, the Ministry of Education, Culture, Sports, Science and Technology, and the Ministry of Economy, Trade and Industry - launched a joint panel to stimulate the use of digital publications.

In the United States, Amazon and Apple began to sell Kindle and $i P a d$ in 2007, respectively. Electronic newspapers and e-books were published for iPhones and iPads. On the other hand in Japan, SHARP sold GALAPAGOS as an e- 
book reader, and NTT DoCoMo sold honto and created E-EVERYSTAR (http://estar.jp/.pc/) as the websites to publish e-books. However, the utilization of these devices decreased precipitously in January 2011 because there

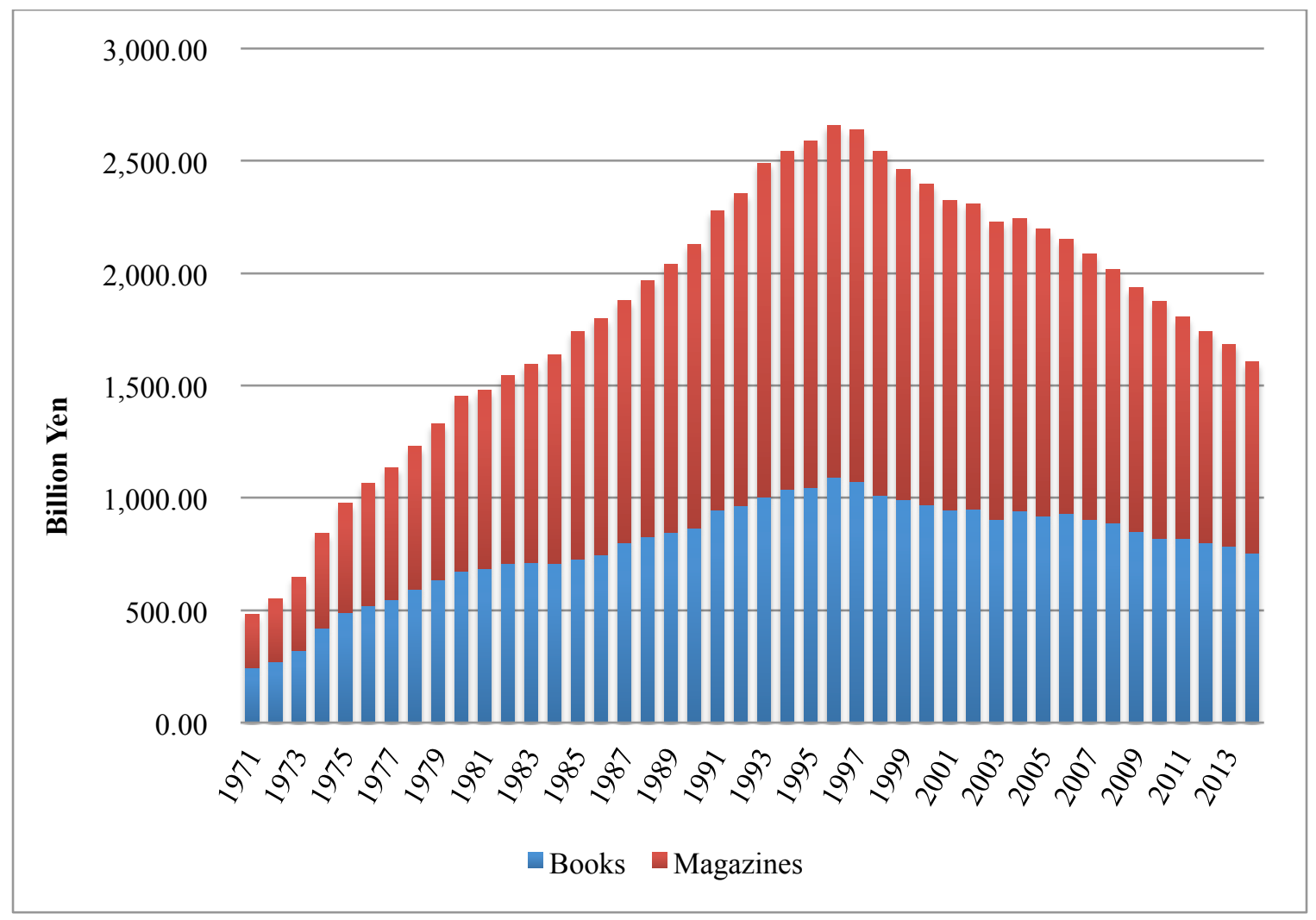

Magazines $\square$ Books

Figure 1. Total Sales Revenue of Books and Magazines

Source: The Association of Japanese Publishers (http://www.ajpea.or.jp/)

were no e-books written in Japanese in the iBook Store, and even Japanese websites had only approximately 20,000 e-books available. In 2011, SONY released PRS-500 for an e-book reading device, and upgraded their e-book websites. However, its contents were still not sufficient enough to attract many customers. In 2012, Kobo of Rakuten, Google Playbooks, and iBooks 3.0 were introduced and finally the number of selections for e-books became adequately plentiful to establish a legitimate e-books market in Japan. Consequently, the year 2012 was widely recognized as the inaugurating year of e-books in Japan.

\section{ADVANTAGES AND DISADVANTAGES OF E-BOOKS}

A hard drive with 100 gigabytes of data storage can hold approximately 75,000 Japanese books containing primarily characters. Thus, a vast amount of physical space can be saved in homes, libraries, and others replacing physical books with e-books. Another advantage is cost reduction for printing, bookbinding, and logistics. Also, e-books can resolve the issue of out-of-print books due to declining orders. Furthermore, e-books can enjoy the additional benefits enabled by electronic devices. For example, e-book users can utilize the included electronic dictionaries and hyperlinks, videos and audio, or even be stimulated with vibrations.

On the other hand, one of the disadvantages of e-books is that they require electric power. Another disadvantage is a Data Lock-In problem where data becomes un-accessible due to obsolescence of the hardware or software. Centuries-old paper books can be read or deciphered by paleography, while e-books can be totally lost once the 


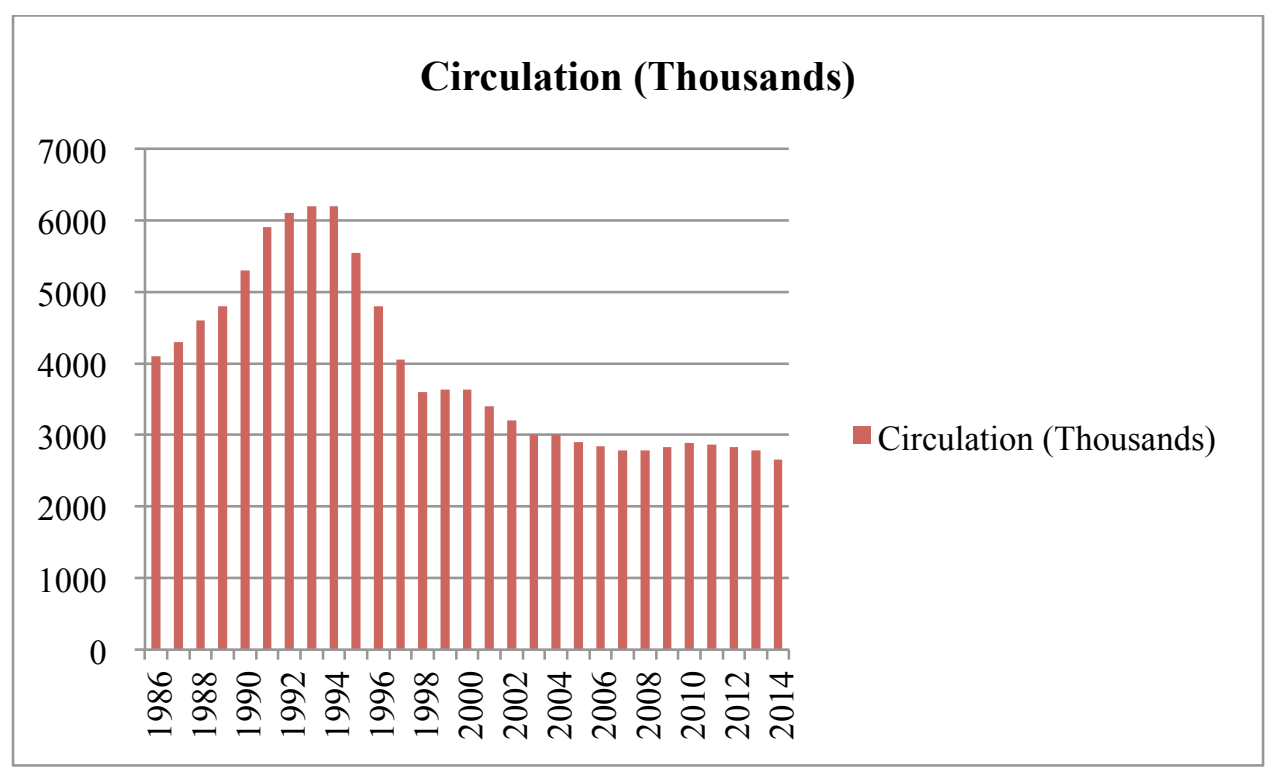

Figure 2. Circulation Figures of the Weekly Shonen Jump

Source: Japan Magazine Publishers Association (http://www.j-magazine.or.jp/data_002/m6.html)

supporting hardware or software technology is no longer available or supported. Finally, for e-books, it is considerably easier to make copies. Therefore unless illegal or unethical copying of digital materials is properly regulated, intellectual property can substantially be violated.

\section{CURRENT STATE OF PUBLISHING INDUSTRY IN JAPAN}

According to the Japanese Publishers Association [11], the total sales revenue of the Japanese publishing industry in 2014 was 1,606.4 billion Yen, including 754.4 billion Yen for books and 852 billion Yen for magazines. Compared to the total revenue in 2010 , this was lower by $16.7 \%$.

As shown in Figure 1, total sales revenue has been decreasing from the height of the 1996's revenue of 2,656.3 billion Yen. Sales of books and magazines topped at 94,379 books in 1998 and 391,060 magazines in 1995, respectively. Also, the total sales revenues were 1,093.1 billion Yen for books in 1996 and 1,564.4 billion Yen in 1997 for magazines, respectively.

One indicating example of the decreasing sales of magazines was the Weekly Shonen Jump. In 1995, the circulation figures of the Weekly Shonen Jump (a combined volume of No. 3 and 4) reached the height of 6.53 million, which was recorded in the Guinness Book of World Records. After the ending of the popular manga (or cartoon) series, however, its circulation went down rather precipitously. The Weekly Shonen Jump won back its market share in August 2002 but its circulation has been on a declining trend as shown in Figure 2.

The declining trend of the magazines' circulation is highly correlated with the birth rate in Japan. According to the demographic statistics [14], the number of births in 2013 was 1.029 million, which was the lowest since 1899. The highest number of births was 2.091 million in 1973 - the year of the second baby-boom in Japan (1971-1974). The number of births in 2013 was approximately half of that in 1973. The Weekly Shonen Jump was recorded in the Guinness Book of World Records in 1995 when there were many 22 year olds, born in 1973. After that, the circulation number has been declining rapidly along with the decrease in birth rates.

The music industry has been experiencing the similar trend as shown in Figure 3. According to the Recording Industry Association of Japan (RIA), the total number of CDs produced was 225,989 and 247,702 units in 2013 and 2014, respectively [18]. Total sales revenue was 270,468 million and 254,176 million Yen in 2013 and 2014, 


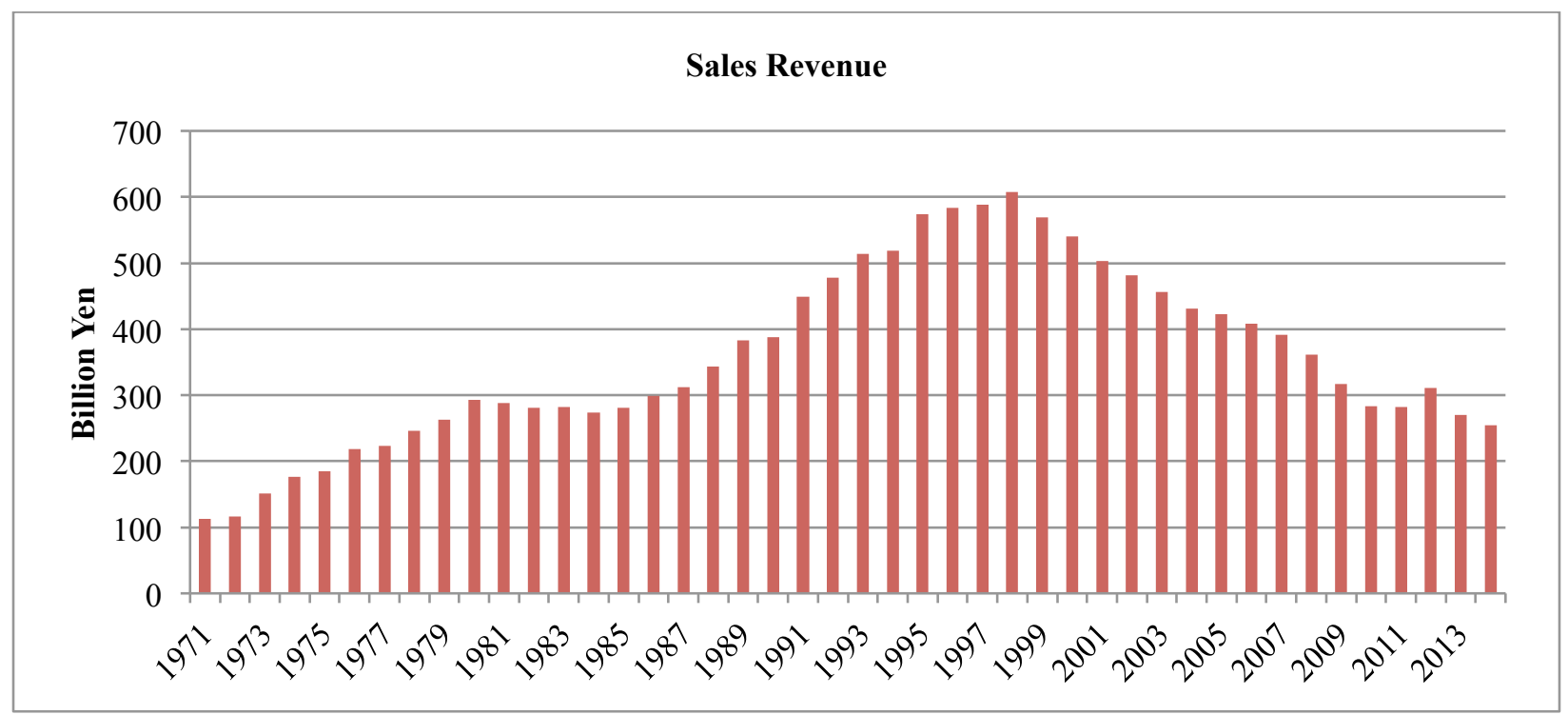

Figure 3. Total Sales Revenue in the Music Industry

Source: Japan Phonograph Record Association (http://www.riaj.or.jp/data/money/)

respectively [17]. The highest number of CDs produced was 480.706 million in 1997 [18], and the largest sales revenue was 607,494 million Yen in 1998 [17]. Both of these figures were more than halved in 2014. The Year 1997 and 1998 were the times when there were the most number of 24 or 25 year olds in the population, who were born in 1973. This decline in CD sales can be proved by the decrease in the number of bookstores. As shown in Figure 4, the number of bookstores has been decreasing since 1999 [10].

The publishing industry in Japan is quite different from that in the United States. Major publishers in Japan have been selling books and magazines while many of those in the United States sell either books or magazines. Furthermore in Japan, there are several major intermediary companies between publishers and bookstores, which deal with books and magazines, and bookstores sell books and magazines via those intermediary companies. One of the characteristic of Japanese publishers is that magazines account for the majority of the sales revenues at major publishers, wholesalers, and bookstores. Figure 5 shows that a sales ratio of major publishers Shueisha, Kodansha, and Shogakukan.

As aforementioned, profits of the Japanese publishing industry primarily depend on their sales of magazines. In many cases, publishers are actually losing money by selling books. Many Japanese publishers started selling e-books motivated by the possibility of reducing the costs for printing, binding and distribution. Furthermore, consumer psychology on books has been shifting from ownership of books to consumption (reading). People used to enjoy seeing books displayed on their bookshelves as well as reading them. Even though they may not read them right away, they know the books will be available by having them on their bookshelves. Since e-books can be available anytime on the Internet, however, possessing or owning physical books has lost its value. We see the same type of changes in consumer psychology in movies. People do not want to buy movies and keep them because they are readily available on Netflix or other service providers. Consequently, we project that the number of small- or medium-sized bookstores will continue to decline in Japan.

\section{CURRENT STATE OF E-BOOKS IN JAPAN}

According to the survey of Ministry of Internal Affairs and Communications in 2010, mangas (comics) account for most of the sales as shown in Figure 6. One of the main differences between Japan and the US is that in Japan, popularity of e-books started primarily from comics being available on cell phones, rather than from e-book readers such as Amazon's Kindle. Since November 28, 2003, KDDI started CDMA 1x WIN service and introduced a flat packet rate system with CDMA 2000 1x EV-DO, which was adopted by Amazon Kindle in 2007. After KDDI 
started the service, Toppan established Bitway, developed a manga viewer system, and started the service of comics station on December 1,2003. Also, Celsys started to offer digital comics via cell phones and to sell at from 31 to 52

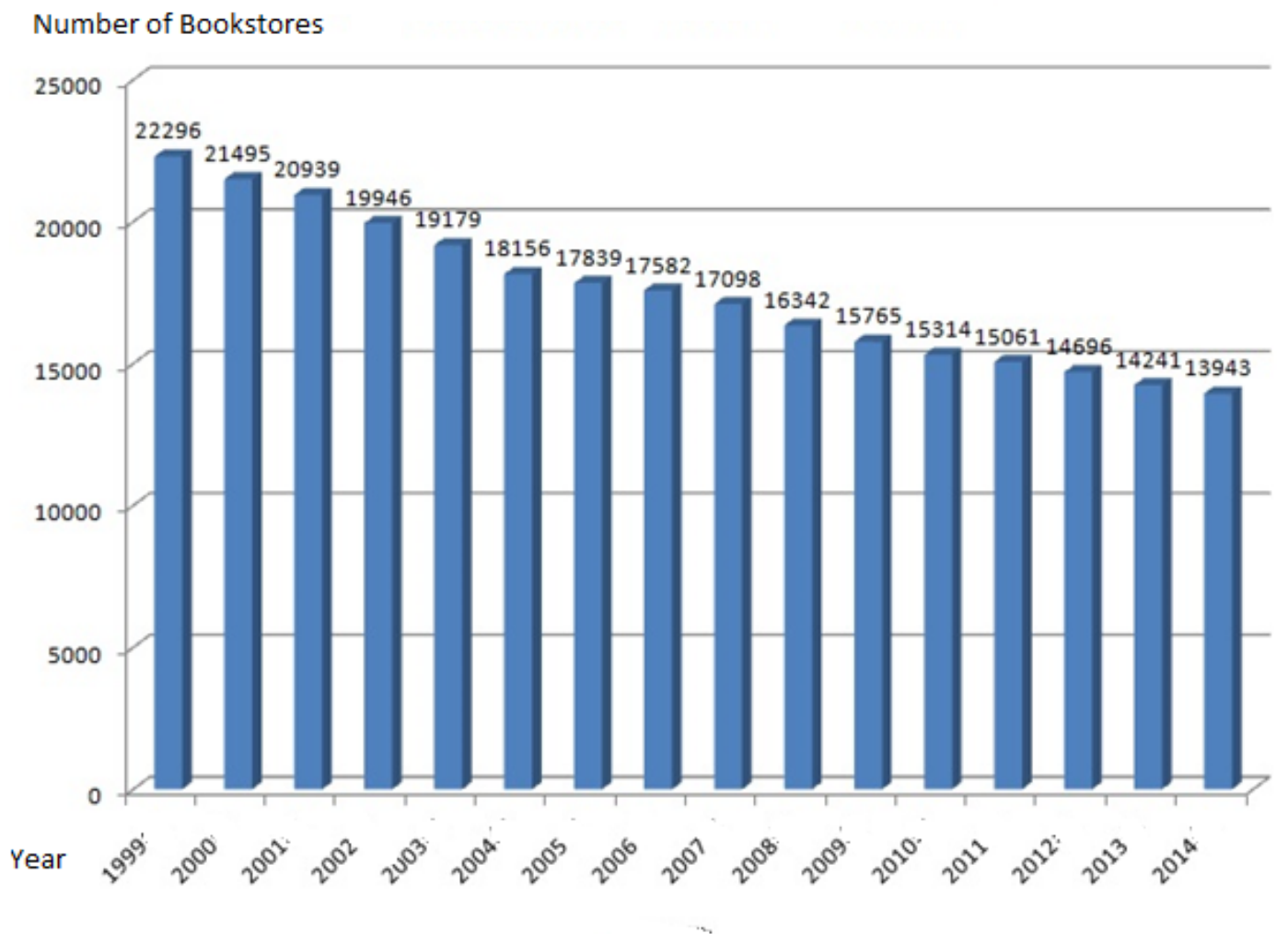

Figure 4. Decreasing Trend of the Number of Bookstores Source: http://www.1book.co.jp/001166.html

Yen per comic. Unlike the US, mobile phones play an important role as a platform for selling digital contents in Japan. As shown in Figure 7, since 2004 sales of mobile contents such as comics and novels have been rising rapidly.

Novels available on cell phones have become quite popular since a novel entitled "Deep Love" was distributed for free on an unofficial $i$-mode website in May 2000. "Deep Love" was published in 2002 by Starts Publishing Corporation and sold over 2.7 million copies [20]. One publisher, Shinchosha, launched a website called Shincho Keitai Bunko [19] and another publisher, Kadokawa Shoten, launched Bunko Yomi Houdai. Mahou No i-Land [12] has been launched to support the production of user generated contents among mobile phone users. One of the most popular novels in Mahou No i-Land was Koizora. As described earlier, EVERYSTAR launched a free website to read novels. They also started a premium site for famous or popular books for 210 Yen per month.

As can be seen in Figure 7, the electronic book markets started from PC users. However, between 2006 and 2012, mobile phones became a primary platform for e-books. From 2013, sales from new types of platforms such as smart phones, tablets, and e-book readers have become more dominant. Figure 7 also indicates that sales in 2011 fell short of that in previous years. The reason was the transition from regular cell phones to smart phones. Another reason for the drop in sales is due to Apple's new policy on pornography (see Table 1). Since the majority of e-book contents in Japan were considered as pornography, according to the Apple Store Guidelines, many e-books could not be registered on the Apple App store. 


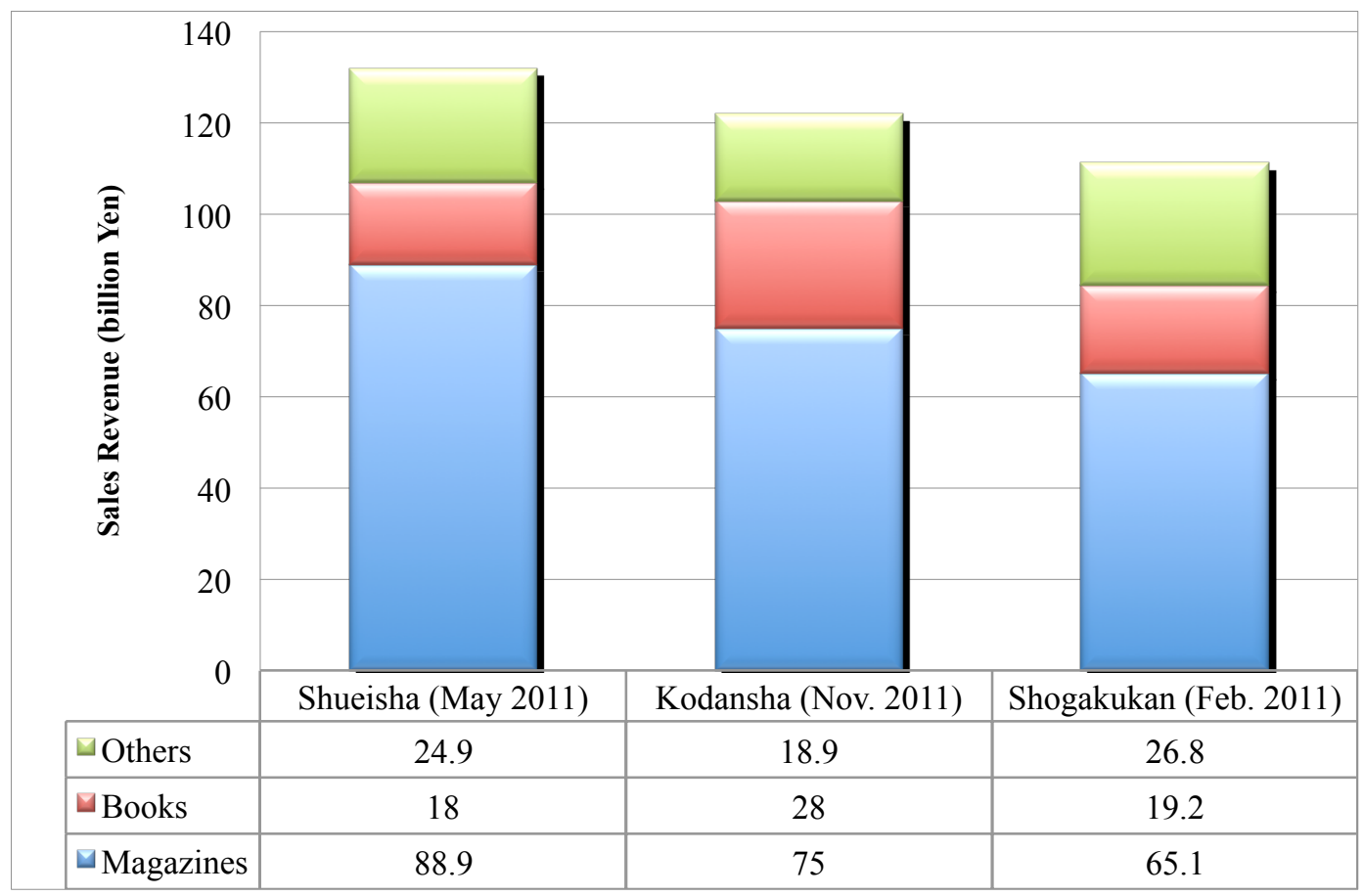

Figure 5. Sales Ratio of Major Publishers in Japan

Sources: http://www.shinbunka.co.jp/kessan/kessan-shueisha.htm http://www.shinbunka.co.jp/kessan/kessan-kodansha.htm http://www.shinbunka.co.jp/kessan/kessan-shogakukan.htm

\section{E-BOOK STORES IN JAPAN}

There are several reasons why there are fewer e-books available in Japan in contrast to the US. While writers in the US usually transfer copyrights to publishers, writers in Japan keep and manage their own copyrights. The copyright for publications as stipulated by Article 79 of the Japanese Copyright Act is not applicable to e-books because ebooks are not considered a document or an image using mechanical or scientific methods. Also, the copyrights of ebooks have still been in progress by the Council for Cultural Affairs of the Agency for Cultural Affairs. Consequently, the number of e-books in Japan is merely around 200,000 while more than two million e-books are available in the US.

Some of the major e-books stores are BookLive!, Rakuten Kobo, BookPass, Kindle, Sony Reader, Sharp Galapagos, Kinokuniya Book Web Plus, and Papyless. The approximate number of e-books carried by these stores are shown in Table 2.

\section{DIGITAL LIBRARIES IN JAPAN}

Digital libraries are defined as a service that can retrieve digital data stored in servers via networks or terminals at libraries. Many public libraries aim to provide more digital services as well as traditional archives, including regional data.

As of 2014, there were 28 National Diet Libraries and public libraries, 62 provincial libraries, 2,526 city libraries, 601 town and village libraries, one metropolitan city library, 20 private libraries and 1,419 university libraries in Japan. 
The main purpose of public libraries is to provide various publications to the general public. Public libraries contain privately established libraries; however, most of them are established by local municipalities.



FIGURE 6. The Average Number of Purchases for each Type of e-Books

Source: Ministry of Internal Affairs and Communications in 2010

http://www.soumu.go.jp/johotsusintokei/linkdata/h22_07_houkoku.pdf page 14

As shown in Figure 8, the number of public libraries has been on the uptrend, as there were 3,248 public libraries in 2013. However, the budget for purchasing publications peaked at 3,697 million Yen in 1997, and it has been showing a downward trend trending down thereafter [16].

\section{Defunct Digital Libraries}

- Iwamizawa City Library

Iwamizawa City Library was established in June 2002. The library provided e-books such as Iwanami Bunko, Toyo Bunko, and some graphic novels in association with the e-books Initiative Japan Company and the Hudson Soft Company. Unfortunately, the service was terminated within two months after opening due to the withdrawals of vendors and few users.

- Ikoma City Library

Ikoma City Library was established in May 2005. The library started its service lending SONY LIBLIe to users with Time Book Town of Publishing Link, which operates Papyless. However, it was terminated in December 2008 due to the suspension of Time Book Town.

\section{Digital Libraries Currently in Operation}

- Chiyoda Web Library

Chiyoda Web Library was established in November 2007. The library provides e-books using Wbook of iNeo for Windows users and DBookReader of KDMT for iOS users. There are around 5,600 e-books: Digital Library from the Meiji Era, Aozora Bunko, Gutenberg 21, Pan Rolling, Impress, and PHP Institute. 
- Sakai City Library

Sakai City Library was established in January 2011. Like the Chiyoda Web Library, the library provides ebooks using Wbook of iNeo for Windows users and DBookReader of KDMT (Korea Digital Media

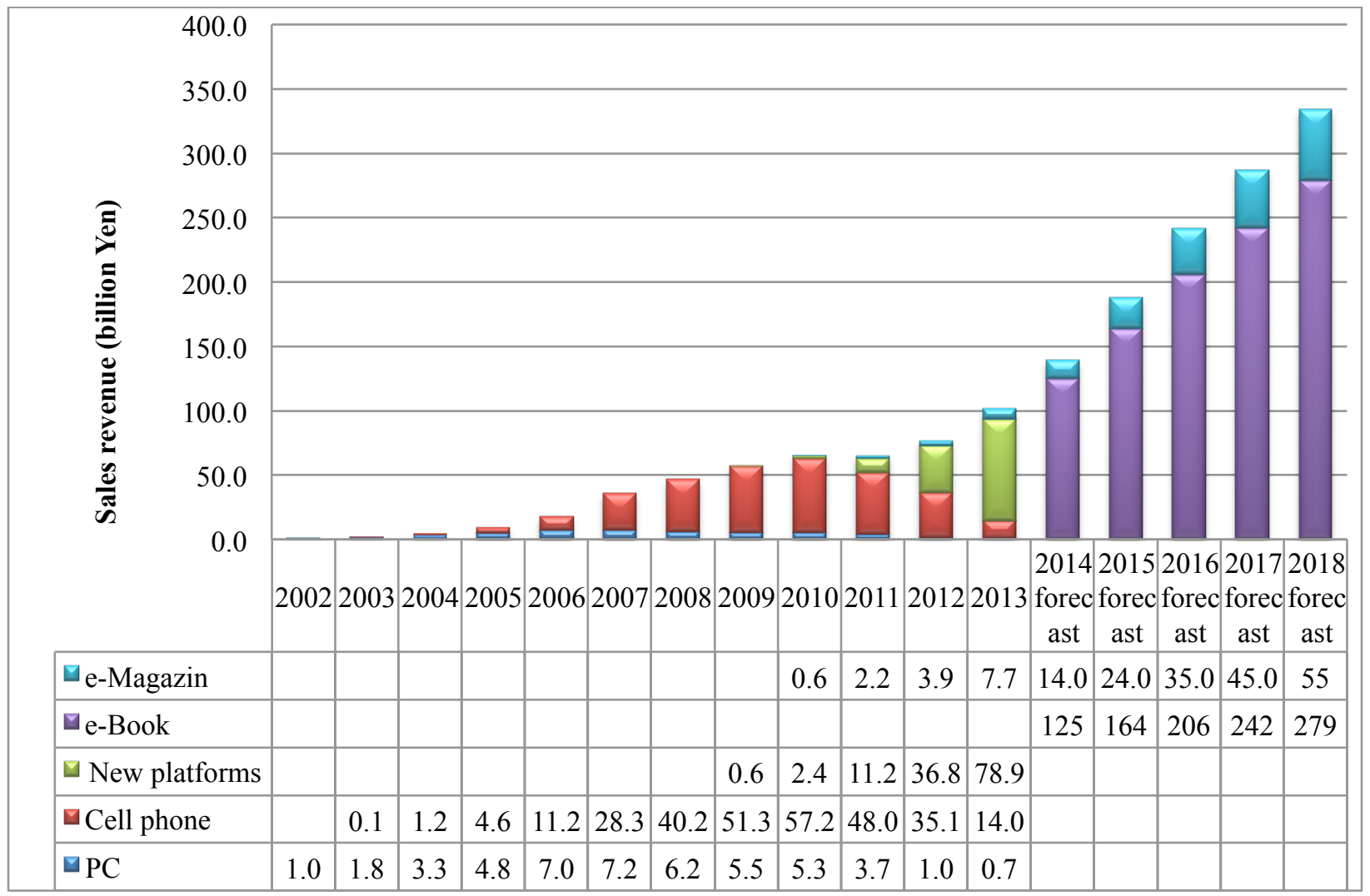

Figure 7. Sales Revenue of e-Marketplace

Source: http://www.impressbm.co.jp/news/140624/ebook2014

Technology Inc.) for iOS users. As recommended by the introduction of library information system using ICT, the library introduced NEC-GPRIME/TRC-DL (iNeo).

- Takeo City Library

Takeo City Library was established as a collaborative project with Keio University in April 2011. The library lends iPads and provides copyrighted works of Takeo city and public domains via a dedicated app. The system was developed by COARA, Computer communication of Oita Research Association.

- $\quad$ Seki City Library

Seki City Library was established in November 2011. The cloud system provides the contents by EBSCO NetLibrary, Kinokuniya Company's agency. Since NetLibrary is an American system, 300,000 foreign books can be browsed in addition to 4,000 Japanese books.

- Akita Prefectural Library

Akita Prefectural Library was established in October 2012. Their web service utilizes FMS Books for iOS users and Keiyou Digital Library for Android users. The number of contents is around 2,000, including precious books, data and magazines. Also, digital magazines such as Weekly Diamond and Rekishi Dokuhon can be browsed. 


\section{Libraries Planning to offer Digital Services}

Libraries planning to offer digital services include the following: Tokyo Metropolitan Library, Nada Library, Kamakura City Library, Shizuoka Prefectural Central Library, Mie Prefectural Library and Sapporo City Library.

Table 1. Apple Store Review Guidelines

18. pornography

- 18.1 Apps containing pornographic material, defined by Webster's Dictionary as "explicit descriptions or displays of sexual organs or activities intended to stimulate erotic rather than aesthetic or emotional feelings," will be rejected.

○ 18.2 Apps that contain user generated content that is frequently pornographic (ex "Chat Roulette" apps) wil rejected.

Source: http://developer.apple.com/app-store/review/guidelines page 18

\section{Libraries Offering Digital Archives}

Many regions in Japan collect and store various materials regarding their local history or any significant events and produce digital archives [15]. The following libraries offer their regional digital archives: Sapporo City Central Library, Akita Prefectural Library, Shizuoka Prefectural Central Library, Mie Prefectural Library, and Shimonoseki Library.

\section{Digital Libraries Providing an Access to Libraries Overseas}

Ichikawa City Library in Japan provides an access to Gangnam City Library in Seoul, Korea.

\section{Advantages and Disadvantages of Digital Libraries}

First of all, one of the main advantages of digital libraries is that users do not physically need to come to the libraries. Digital libraries can offer 24/7 service even during the days when libraries are closed. Secondly, there are no technical limitations on the number of rentals for one copy of a book. Thirdly, there will be no physical damage or loss of books, and spaces for physical books are not an issue. Most library procedures such as processing rentals, returns, fines, late submissions etc. can be automated. Also, specific words can now be searched while only metadata could be used in the past. In addition, books that users search can be retrieved very efficiently. Finally, adjusting the size of the fonts or audio book players enabled by digitization can help people with disability read better.

On the other hand, as aforementioned, the number of e-books is still relatively small and insufficient. There are approximately only 770,000 e-books on average at a public library. Moreover, e-books are more expensive than printed books in Japan [3]. Currently, production costs and service fees for producing e-books are not necessarily lower than the costs for books. Furthermore, DRM (Digital Rights Management) has not yet been well implemented. For example, when downloading a book from a publisher's site such as Kinokuniya [13], the downloaded books can remain in the buyer's machine, and even be manipulated to include footprints of the buyer's information and watermarks. This downloaded book can cause a violation of digital rights. We believe there is plenty of room for improvement in digital rights management. Finally, in case of inter-library loans, how to handle digital rights among libraries still remains an unresolved issue.

\section{CONCLUSIONS}

Development of e-books in Japan still needs more time due to a slow increase of contents available. Authors' rights transferred to publishers do not usually include a right for electronic publication to produce e-books. Furthermore, it is sometimes hard to locate the authors to acquire the right to publish e-books. In many cases, there are still no clear written contracts between publishers and authors to clearly specify the rights of each party. In addition to these legal issues and legacy problems of the publishing industry, one of the main reasons for Japan's sluggish move to e-books 
is that Japan could not establish a consensus on technology standards among the stakeholders even though Japan has high levels of technology. Since 2011, Amazon has already started Kindle Owner's Lending Library, where Prime members can rent a free e-book every month among 200,000 titles. This service has also started in the United Kingdom, Germany, and France since 2012.

More business models similar to Kindle Owner's Lending Library will emerge soon. Unfortunately in Japan, a strong leadership like the one in Korea has been lacking, and Japanese management tends to be very risk-averse. Furthermore, as discussed in Nagao's Framework, there are plenty of criticism rather than innovation in Japan. Unless these issues are resolved, Japanese e-books and digital libraries may not be fully developed in the near future. This situation is similar to the fact that Japan could not build de facto standards in software even though the Japanese IT industry established a firm position in the field of hardware.

\section{REFERENCES}

1. Aozora Bunko (2014). Retrieved March 9 19, 2015 from http://www.aozora.gr.jp/aozora_bunkono_shikumi.html

2. Asta muse project (2015). Retrieved April 18, 2015 http://shohyo.shinketsu.jp/decision/tm/view/ViewDecision.do?number=1072147

3. Bailey, T. P., Scott, A. L., \& Best, R. D. (2015). Cost Differentials between E-Books and Print in Academic Libraries. College \& Research Libraries, 76(1), 6-18.

4. Current Awareness Portal (2015). Retrieved on March 7, 2015 http://current.ndl.go.jp/node/14622

5. EBSCO (2015). Retrieved on March 7, $2015 \mathrm{https} / / /$ www.ebsco.com

6. Gardiner, E. \& Musto, R. G. (2010) The Electronic Book. In Suarez, M. \& Woudhuysen, H. R. (Ed.), The Oxford Companion to the Book (p. 164). Oxford: Oxford University Press

7. Hart, M., (2007). Project Gutenberg Mission Statement. Retrieved January 19, 2015 from http://www.gutenberg.org/wiki/Gutenberg:Project_Gutenberg_Mission_Statement_by_Michael_Hart

8. Impress, (2013). A Research Report 2013 on E-Books Business, Retrieved January 19, 2015 from http://www.impressbm.co.jp/news/130627/ebook2013

9. Indvik, L., (2012). Ebook Sales Surpass Hardcover for First Time in U.S. Retrieved January 12, 2015 from http://mashable.com/2012/06/17/ebook-hardcover-sales

10. Japan Author Promotion Center (2014). Retrieved March 5, 2015 http://www.1book.co.jp/001166.html

11. Japanese Publishers Association (2014). Retrieved January 19, 2015 from http://www.ajpea.or.jp

12. Kadokawa Corporation (2015). Retrieved January 19, 2015 http://maho.jp

13. Kinokuniya (2015). Retrieved on March 7, 2015 http://www.kinokuniya.co.jp/03f/oclc/netlibrary/netlibrary_ebook.htm

14. Ministry of Health, Labor and Welfare (2014). Retrieved March 4, 2015 http://www.mhlw.go.jp/toukei/list/d1/81-1a2.pdf

15. National Diet Library (2015). Retreived on March 7, 2015 http://www.ndl.go.jp/jp/aboutus/dlib/cooperation/working_group.html

16. Public Library (2013). Retrieved March 5, http://www.jla.or.jp/Portals/0/data/iinkai/\%E5\%9B\%B3\%E6\%9B\%B8\%E9\%A4\%A8\%E8\%AA\%BF\%E6\%9F \%BB\%E4\%BA\%8B\%E6\%A5\%AD\%E5\%A7\%94\%E5\%93\%A1\%E4\%BC\%9A/2013_p24-25.pdf

17. RIA-Revenue (2014). Retrieved March 4, 2015 http://www.riaj.or.jp/data/money

18. RIA-Quantity (2014). Retrieved March 4, 2015 http://www.riaj.or.jp/data/quantity

19. Shichosha (2002). Retrieved January 19, 2015 from http://www.jepa.or.jp/sm/siryositu/20021211.files/frame.html

20. Yoshi (2015). Retrieved March 5, 2015 http://zavn.net/pc/profile

** Figure 8 and Table 2 will be available upon request. 